\title{
Sviktende kvalitet på muntlig legemiddelreklame
}

\author{
Siden 2007 har representanter for Legemiddelverket møtt opp på legekontorer og andre møter for å følge \\ med på muntlig legemiddelreklame. Er kvaliteten på den muntlige informasjonen bedre enn for den skrift- \\ lige? Dessverre viser vår erfaring at det ikke står bra til.
}

Fra høsten 2007 til og med 2013 var vi til stede på 79 møter mellom legemiddelindustri og leger, de fleste på allmennlegekontorer. Legemiddelforskriften stiller krav til reklamens innhold og form (ramme 1) (1). Vi bedømmer presentasjonene som gis ut fra disse reglene. Indikasjon, advarsler og forsiktighetsregler, kontraindikasjoner, bivirkninger og refusjonsregler skal alltid omtales. For at vi skal anse en reklamepresentasjon som tilstrekkelig balansert, må disse elementene omtales på en slik måte at legene får et korrekt inntrykk av nytte og risiko ved legemidlet. Bare i 18 av 79 $(23 \%)$ tilfeller var informasjonen tilfredsstillende ut ifra kriteriene i legemiddelforskriften. Resultatene er oppsummert i tabell 1. Kvaliteten ser dessverre ikke ut til å ha blitt bedre de siste årene. Resultatene samsvarer med tidligere undersøkelser av skriftlig reklame $(2,3)$ og informasjon som blir gitt ved konsulentbesøk på legekontorer (4).

\section{Ubalansert informasjon}

Vi velger stedene for våre inspeksjoner ut ifra en «risikostrategi» der vi legger vekt på om det er et nytt legemiddel, om det er risiko for feilbruk, særlig intens markedsføring, høye samfunnskostnader eller konkurranse mellom flere legemiddelfirmaer. Det er mulig at en slik strategi kan føre til at vi påviser en høyere andel feil og mangler enn det som forekommer gjennomsnittlig. Imidlertid tror vi det er særlig viktig at markedsføringen av nye legemidler er mest mulig korrekt. De vanligste manglene ved

\section{«Resultatene av våre og andres reklame- undersøkelser er lite flatterende for lege- middelindustrien»}

de muntlige presentasjonene var ubalansert informasjon om nytte-risiko ( $52 \%$ av presentasjonene) og mangelfull informasjon om refusjon $(29 \%)$. Dette kan bidra til uheldig bruk både medisinsk og økonomisk.

Etter hver inspeksjon skriver vi en rapport til legemiddelfirmaet om de funnene vi har gjort. Fra 2014 har vi skjerpet våre rutiner, slik at vi nå sender et forhåndsvarsel der vi påpeker de mangler som må rettes opp. Ved manglende etterlevelse av

Tabell 1 Resultat av inspeksjoner

\begin{tabular}{|c|c|c|c|}
\hline$\AA ̊$ & $\begin{array}{c}\text { Antall } \\
\text { inspeksjoner }\end{array}$ & $\begin{array}{l}\text { Antall presentasjoner } \\
\text { med feil og mangler }\end{array}$ & $\begin{array}{l}\text { Påviste feil og mangler (I noen tilfeller } \\
\text { var det flere typer feil i samme presentasjon) }\end{array}$ \\
\hline 2007 & 1 & $1(100 \%)$ & Mangelfull informasjon om refusjon: 1 \\
\hline 2008 & 7 & $7(100 \%)$ & $\begin{array}{l}\text { Mangelfull informasjon om refusjon: } 4 \\
\text { Ubalansert informasjon om nytte-risiko: } 3 \\
\text { Markedsføring utenfor godkjent indikasjon: } 2\end{array}$ \\
\hline 2009 & 14 & $11(79 \%)$ & $\begin{array}{l}\text { Ubalansert informasjon om nytte-risiko: } 6 \\
\text { Mangelfull informasjon om refusjon: } 3 \\
\text { Markedsføring utenom godkjent indikasjon: } 2\end{array}$ \\
\hline 2010 & 10 & $8(80 \%)$ & $\begin{array}{l}\text { Ubalansert informasjon om nytte-risiko: } 5 \\
\text { Mangelfull informasjon om refusjon: } 4 \\
\text { Markedsføring utenom godkjent indikasjon: } 2\end{array}$ \\
\hline 2011 & 15 & $5(33 \%)$ & Ubalansert informasjon om nytte-risiko: 5 \\
\hline 2012 & 18 & $15(83 \%)$ & $\begin{array}{l}\text { Ubalansert informasjon om nytte-risiko: } 12 \\
\text { Mangelfull informasjon om refusjon: } 5 \\
\text { Markedsføring utenom godkjent indikasjon: } 2\end{array}$ \\
\hline 2013 & 14 & $14(100 \%)$ & $\begin{array}{l}\text { Ubalansert informasjon om nytte-risiko: } 10 \\
\text { Mangelfull informasjon om refusjon: } 6\end{array}$ \\
\hline
\end{tabular}

RAMME 1

Regler for reklame i legemiddelforskriften Legemiddelforskriften § 13-3

Reklame for legemidler skal være nøktern og saklig. Den skal fremme rasjonell bruk i henhold til gjeldende forskrivningsregler. Reklamen må ikke gi et misvisende eller overdrevet bilde av et legemiddels egenskaper og medisinske verdi. Reklamen må ikke føre til bruk av legemidlet som ikke er medisinsk begrunnet.

Legemiddelforskriften $\S$ 13-7 (utdrag) $\S 13-7$. Krav til reklame til helsepersonell Reklame for reseptpliktige legemidler kan bare rettes mot leger, tannleger, veterinærer, fiskehelsebiologer, offentlig godkjente sykepleiere og farmasøyter samt studenter i disse fag og andre faggrupper etter departementets nærmere bestemmelse. Reklamen skal være fyllestgjørende. Reklamen skal inneholde opplysninger på følgende punkter:

a) navn på legemidlet samt doseringsform og styrke

b) navn på alle virkestoff skal trykkes med tydelige typer og gis en fremtredende plass

c) navn på innehaver av markedsføringstillatelse og ev. produsent

d) godkjent bruksområde

e) kontraindikasjoner

f) bivirkninger, forsiktighetsregler og interaksjoner

g) dosering

h) pakningsstørrelse(r)

i) reseptgruppe, forskrivningsregler og utleveringsbestemmelser

j) godkjent utsalgspris pr. angitt dato og refusjonsbestemmelse.

pålegg kan vi nedlegge forbud mot reklame $i$ kortere eller lengre tid.

Da vi begynte med våre inspeksjoner i 2007, ble vi møtt med sterk motstand både fra legemiddelindustrien og legene. Vi har imidlertid møtt få motforestillinger ute hos leger i praksis, og bare ved ett tilfelle er vi blitt avvist. Det gjaldt et konsulentbesøk med etterfølgende middag betalt av legemiddelfirmaet $\mathrm{i}$ et privat hjem. 


\section{Konkrete tiltak kreves}

Resultatene av våre og andres reklameundersøkelser er lite flatterende for legemiddelindustrien, og vi mener industrien snarest bør gjennomføre konkrete tiltak for å rette opp situasjonen. Retningslinjene for legemiddelindustriens helse- og sykdomsinformasjon til allmennheten er nylig endret (5). Det er etter vår mening særlig viktig at slik informasjon holder høy faglig standard. Legemiddelverket vil fortsette med sin overvåking av reklamen, men ansvaret ligger til syvende og sist hos det enkelte legemiddelfirma og bransjen som helhet. Legemiddelindustrien har signalisert at Rådet for legemiddelinformasjon skal ta et større ansvar for kvaliteten til industriens markedsføring (6). Det er på høy tid.

\section{Steinar Madsen}

steinar.madsen@legemiddelverket.no

Bente Jerkø

Steinar Madsen (f. 1956) er spesialist i indremedisin og i hjertesykdommer og medisinsk fagdirekt $\varnothing r$ i Statens legemiddelverk.

Forfatter har fylt ut ICMJE-skjemaet og oppgir ingen interessekonflikter.

Bente Jerkø (f. 1953) er farmasøyt og seniorrådgiver i Statens legemiddelverk.

Forfatter har fylt ut ICMJE-skjemaet og oppgir ingen interessekonflikter.

\section{Litteratur}

1. FOR-2009-12-18-1839. Forskrift om legemidler (legemiddelforskriften). www.lovdata.no/ dokument/SF/forskrift/2009-12-18-1839 [15.12.2014].

2. Solhaug HR, Indermo H, Slørdal L et al. Skriftlig legemiddelreklame - til å stole på? Tidsskr Nor Lægeforen 2006; 126: 1314-7.

3. Gladsø KH, Garberg HR, Spigset 0 et al. Skriftlig legemiddelreklame - fremdeles ikke til å stole på? Tidsskr Nor Legeforen 2014; 134: 1563-8.

4. Straand J, Christensen IJ. Kvaliteten på legemiddelkonsulentbesøk i allmennpraksis. Tidsskr Nor Legeforen 2008; 128: 555-7.

5. Statens legemiddelverk. Enklere for legemiddelindustrien å gi helse- og sykdomsinformasjon. www.legemiddelverket.no/Nyheter/Andre/Sider/ Enklere-for-legemiddelindustrien-\%C3\%A5-gihelseinformasjon.aspx (15.12.2014).

6. Legemiddelindustrien. Nye tiltak for å heve reklamekvaliteten. www. Imi.no/aktuelt-fra-Imi/2014/ 12 /nye-tiltak-for-aa-heve-reklamekvaliteten (15.12.2014).

Mottatt 16.12. 2014 og godkjent 22.12. 2014

Redaktør: Erlend Hem.

Publisert først på nett. 